\title{
A surveillance survey for lentil anthracnose in Victorian lentil crops using high throughput PCR testing
}

\author{
A. Freeman • M. Spackman • K. Lindbeck
}

Received: 14 May 2012 / Accepted: 9 October 2012 /Published online: 7 November 2012

(C) Australasian Plant Pathology Society Inc. 2012

\begin{abstract}
Lentil anthracnose, caused by Colletotrichum truncatum sensu lato, poses a serious threat to the Australian lentil industry, and is ranked by Plant Health Australia as the highest exotic fungal threat to lentil. This is the first report of PCR used as a specific, sensitive and rapid test in a field surveillance survey for lentil anthracnose (C. truncatum sensu lato) in the lentil growing areas of Victoria.
\end{abstract}

Keywords Lentil · Lentil anthracnose · Surveillance survey $\cdot$ PCR

\section{Introduction}

The causal pathogen of lentil anthracnose, Colletotrichum truncatum sensu lato, has an extensive distribution world wide, including Australia. The disease, lentil anthracnose, has been recorded world-wide in lentil producing countries such as Canada, the USA, Syria, Pakistan and Brazil (Lindbeck and Ford 2005). In Australia, C. truncatum sensu lato has been recorded on peanut (Arachis hypogea) and soybean (Glycine max) (Lindbeck and Ford 2005) but has never been observed in the field on lentil, despite extensive commercial lentil crop surveys throughout Victoria and South Australia for disease symptoms, including 85 crops in 2001 and 41 crops in 2002 (Lindbeck, unpublished data).

A. Freeman $(\bowtie) \cdot$ M. Spackman

Department of Primary Industries, Biosciences Research Division,

Natimuk Rd,

Horsham, Victoria 3400, Australia

e-mail: angela.freeman@dpi.vic.gov.au

K. Lindbeck

Industry \& Investment NSW, Wagga Wagga Agricultural Institute, Pine Gully Road,

Wagga Wagga, NSW 2650, Australia
In recent years the identification and nomclature surrounding strains of $C$. truncatum from lentil has been a topic of review and currently is not entirely clear. Gossen et al. (2009) suggested separation of $C$. truncatum that causes anthracnose on soybean from $C$. truncatum that causes anthracnose on lentil based on host specificity and latent infection studies. Detailed taxonomic and phylogenetic studies by Damm et al. (2009) and Latunde-Dada and Lucas (2007) suggested that lentil infecting isolates of $C$. truncatum appear to be more closely related to $C$. destructivum or fall within the $C$. destructivum clade, rather than $C$. truncatum. This discussion is outside the scope of this paper and for the purposes of this study the causal organism will be referred to as $C$. truncatum sensu lato.

C. truncatum sensu lato has a wide host range and there is sufficient evidence to suggest that there are host specific pathotypes, based on both morphological differences in spores and molecular analysis (Lindbeck and Ford 2005). Molecular analysis, using both RAPD markers and 18-25S rDNA sequences, demonstrated the genetic relatedness of $C$. truncatum sensu lato isolates from the same host species and discriminated among isolates from lentil and other host species (Ford et al. 2004). The findings of Ford et al. (2004) were used to develop the diagnostic test outlined by Lindbeck and Ford (2005). It is important to note that while the exact nomenclature of the isolates used is under review the isolates used in the study were Colletotrichum sp. sourced from infected lentil plants in Canada.

Lentil anthracnose was recognised as an economically important disease when discovered in Canada in 1987 (Morrall 1997). Rapidly developing stem lesions cause dieback, premature ripening and potential yield losses of up to $60 \%$. C. truncatum sensu lato is not highly seed-borne in lentil and it is rare to find seed with more than $3 \%$ infection, even when it comes from severely infested crops (Morrall 1997). Buchwaldt et al. (1996) studied the dispersal of anthracnose and found there was potential for wind to 
disperse anthracnose inoculum within old lentil trash, especially when aided by modern harvesting methods and the microsclerotia of $C$. truncatum sensu lato that are produced within lesions have considerable longevity, surviving up to 4 years in soil.

Evaluation of advanced Australian lentil breeding lines and commercial cultivars in Canada has shown all material to be highly susceptible to lentil anthracnose and therefore this disease poses a serious threat to the Australian lentil industry. It is ranked by Plant Health Australia as the highest exotic fungal threat to lentil. An incursion of the lentilattacking strain of $C$. truncatum sensu lato, initiating lentil anthracnose, would result in a dramatic reduction in the area of commercial lentil production due to increased costs of production rendering lentil production less economically competitive. Host range testing in Canada has shown that faba bean and vetch are also highly susceptible when inoculated with isolates of $C$. truncatum sensu lato from lentil (Buchwaldt et al. 1996). Glasshouse testing in Canada has also shown that field pea can become infected but symptoms are mild (Morrall et al. 1989).

Lentil anthracnose can be diagnosed classically by foliar symptoms but may easily be mistaken for other common foliar diseases, such as Ascochyta blight (Ascochyta lentis) or Botrytis grey mould (Botrytis cinerea and B. fabae) (Lindbeck and Ford 2005). Characteristic structures of anthracnose such as setae and microsclerotia may not always be present at the time of sampling and while these structures will develop under the correct conditions this can take up to $36 \mathrm{~h}$. Here we report the first use of a PCR diagnostic test in a large-scale targeted survey for $C$. truncatum sensu lato that was undertaken in the lentil production areas in northern
Victoria during October and November, 2007. This PCR offers a specific and rapid test that is sensitive enough to detect low quantities of target DNA in the absence of disease symptoms.

\section{Materials and methods}

Fifty-one crops from across the lentil production areas of northern Victoria were sampled and variety and GPS coordinates were recorded (Table 1). A total of 2,040 plants were collected. For testing, plants were pooled into four groups of 10 for each of the 51 crops. Samples were kept for retesting individually in the event of any positive samples being found. DNA extractions were carried out using high throughput methodology in a 96 well plate format using a standard DNeasy extraction kit method (Qiagen ${ }^{\circledR}$ ). PCR was carried out with Brilliant ${ }^{\circledR}$ SYBR $^{\circledR}$ green QPCR master mix (Stratagene) and the lentil anthracnose specific primers, CTFP2 and CTRP1 from the internal transcribed spacer (ITS) regions of the 18-25S ribosomal DNA sequence (Lindbeck and Ford 2005) designed to amplify DNA from only the lentil-attacking pathotype of $C$. truncatum sensu lato. DNA of lentil-attacking isolates from Canada was used as positive controls. The Canadian isolates used were isolates 99-70,946 and 99-72,126 sourced from Saskatchewan and supplied by Lone Buchwaldt, Agriculture and Agri-Food Canada, Saskatoon, Canada (Ford et al. 2004). Healthy plant material and no template controls (NTC) were used as negative controls. For analysis of results, the detection thresholds on the QRT-PCR machine (Corbett rotor-gene 3000) were set at Fluorescence $=20,000$

Table 1 Variety and location of lentil crops surveyed across the Victorian lentil production area

\begin{tabular}{ll}
\hline Variety & GPS Co-ordinates \\
\hline Unknown & $-35.41681^{\circ} \mathrm{S} 142.16052^{\circ} \mathrm{N},-35.73754^{\circ} \mathrm{S} 142.29583^{\circ} \mathrm{N},-35.74905^{\circ} \mathrm{S} 142.20254^{\circ} \mathrm{N},-35.69232^{\circ} \mathrm{S} 142.46765^{\circ} \mathrm{N}$, \\
& $-35.99786^{\circ} \mathrm{S} 142.63396^{\circ} \mathrm{N},-35.96477^{\circ} \mathrm{S} 142.7318^{\circ} \mathrm{N},-35.63136^{\circ} \mathrm{S} 142.91402^{\circ} \mathrm{N},-35.70408^{\circ} \mathrm{S} 143.36669^{\circ} \mathrm{N}$, \\
& $-35.62062^{\circ} \mathrm{S} 143.03468^{\circ} \mathrm{N},-35.85401^{\circ} \mathrm{S} 142.09421^{\circ} \mathrm{N},-35.87028^{\circ} \mathrm{S} 143.17319^{\circ} \mathrm{N}$ \\
Aldinga & $-36.47001^{\circ} \mathrm{S} 142.10476^{\circ} \mathrm{N},-36.71153^{\circ} \mathrm{S} 142.52225^{\circ} \mathrm{N}$ \\
Cobber & $-36.57061^{\circ} \mathrm{S} 142.20688^{\circ} \mathrm{N}$ \\
Digger & $-36.07273^{\circ} \mathrm{S} 142.66311^{\circ} \mathrm{N},-36.22819^{\circ} \mathrm{S} 141.88102^{\circ} \mathrm{N},-36.68404^{\circ} \mathrm{S} 142.04443^{\circ} \mathrm{N}$ \\
Digger + Nugget & $-36.38989^{\circ} \mathrm{S} 142.39422^{\circ} \mathrm{N}$ \\
Northfield & $-36.50864^{\circ} \mathrm{S} 142.55817^{\circ} \mathrm{N},-36.17595^{\circ} \mathrm{S} 142.49588^{\circ} \mathrm{N},-36.02708^{\circ} \mathrm{S} 142.54366^{\circ} \mathrm{N},-36.74422^{\circ} \mathrm{S} 141.93373^{\circ} \mathrm{N}$ \\
Northfield + Nugget & $-36.54722^{\circ} \mathrm{S} 143.18601^{\circ} \mathrm{N},-36.3412^{\circ} \mathrm{S} 142.66495^{\circ} \mathrm{N}$ \\
Nugget & $-35.87338^{\circ} \mathrm{S} 142.98527^{\circ} \mathrm{N},-35.77715^{\circ} \mathrm{S} 143.03307^{\circ} \mathrm{N},-35.55379^{\circ} \mathrm{S} 142.9972^{\circ} \mathrm{N},-35.56253^{\circ} \mathrm{S} 142.99676^{\circ} \mathrm{N}$, \\
& $-35.38307^{\circ} \mathrm{S} 143.51843^{\circ} \mathrm{N},-35.47944^{\circ} \mathrm{S} 143.37709^{\circ} \mathrm{N},-35.45704^{\circ} \mathrm{S} 143.52883^{\circ} \mathrm{N},-36.45683^{\circ} \mathrm{S} 142.32789^{\circ} \mathrm{N}$, \\
& $-36.19338^{\circ} \mathrm{S} 142.21256^{\circ} \mathrm{N},-36.23694^{\circ} \mathrm{S} 142.06524^{\circ} \mathrm{N},-36.38517^{\circ} \mathrm{S} 142.01949^{\circ} \mathrm{N},-36.46903^{\circ} \mathrm{S} 142.73155^{\circ} \mathrm{N}$, \\
& $-36.46979^{\circ} \mathrm{S} 142.24916^{\circ} \mathrm{N},-36.36157^{\circ} \mathrm{S} 142.19081^{\circ} \mathrm{N},-36.21236^{\circ} \mathrm{S} 141.42411^{\circ} \mathrm{N},-36.21579^{\circ} \mathrm{S} 141.75871^{\circ} \mathrm{N}$, \\
& $-36.41388^{\circ} \mathrm{S} 141.20307^{\circ} \mathrm{N},-36.36185^{\circ} \mathrm{S} 141.55654^{\circ} \mathrm{N},-35.88891^{\circ} \mathrm{S} 142.40768^{\circ} \mathrm{N},-35.7662^{\circ} \mathrm{S} 142.04585^{\circ} \mathrm{N}$, \\
& $-35.91023^{\circ} \mathrm{S} 142.01209^{\circ} \mathrm{N},-35.89821^{\circ} \mathrm{S} 142.53709^{\circ} \mathrm{N},-36.81933^{\circ} \mathrm{S} 142.32071^{\circ} \mathrm{N},-36.79797^{\circ} \mathrm{S} 142.50359^{\circ} \mathrm{N}$, \\
& $-36.66648^{\circ} \mathrm{S} 141.61514^{\circ} \mathrm{N},-36.29792^{\circ} \mathrm{S} 142.55267^{\circ} \mathrm{N},-36.63936^{\circ} \mathrm{S} 142.67674^{\circ} \mathrm{N}$ \\
\hline
\end{tabular}


Fig. 1 RT-PCR results: a Electrophoretic analysis of RT-PCR products with $\mathrm{M}$ showing Bioline easy ladder1 size marker; lanes 1-64 survey samples; b Real-time PCR raw fluorescence data curves with detection thresholds set at Fluorescence $=20,000 \mathrm{dR}$ (Y-axis) and Cycle length $=$ 30 cycles. Control reactions: $\mathrm{N}$ (negative), + 1 (Canadian lentil anthracnose strain 99 $70,946)+2$ (Canadian lentil anthracnose strain 99-72,126) and NTC (no template control)

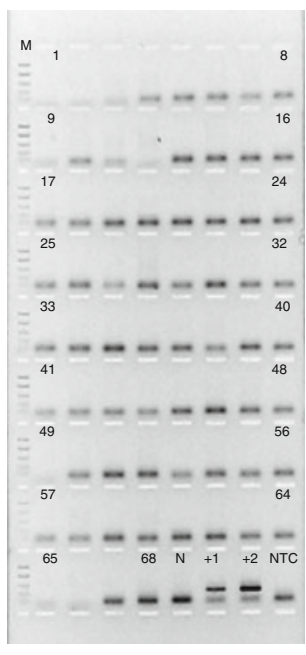

a

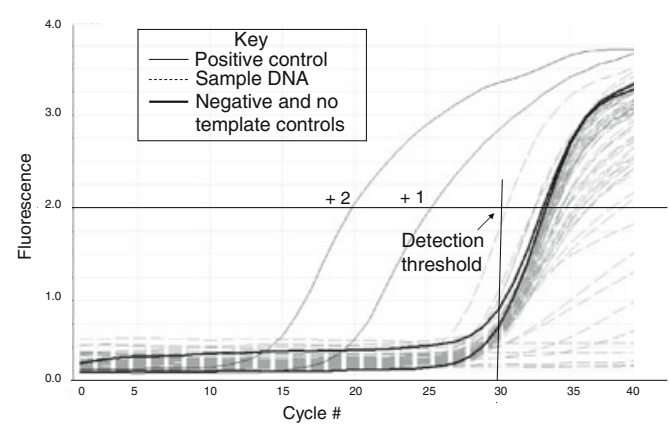

b
$\mathrm{dR}$ (Y-axis) and Cycle length $=30$ cycles to exclude false positives. Results were confirmed on $1.4 \%$ agarose using the ElectroFast ${ }^{\circledR}$ high throughput gel tanks (ABgene) and visualised under UV with $\mathrm{SYBR}^{\circledR}$ safe DNA gel stain (Invitrogen).

\section{Results}

DNA was amplified from the positive controls and not from the negative controls indicating specific, non contaminated reactions. PCR using primers derived from Medicago myb genes designed to amplify genomic plant DNA yielded the expected size fragment in a selection of survey samples, indicating that the DNA is non-degraded (results not shown). No product was amplified from the 204 pooled samples (representing 2,040 samples) from the 51 Victorian lentil crops tested indicating no evidence of lentil specific C. truncatum sensu lato in the DNA samples (Fig. 1). The results were mapped against the crop locations (Fig. 2).
Fig. 2 Location of sample sites in north west Victoria. All samples tested negative for lentil anthracnose

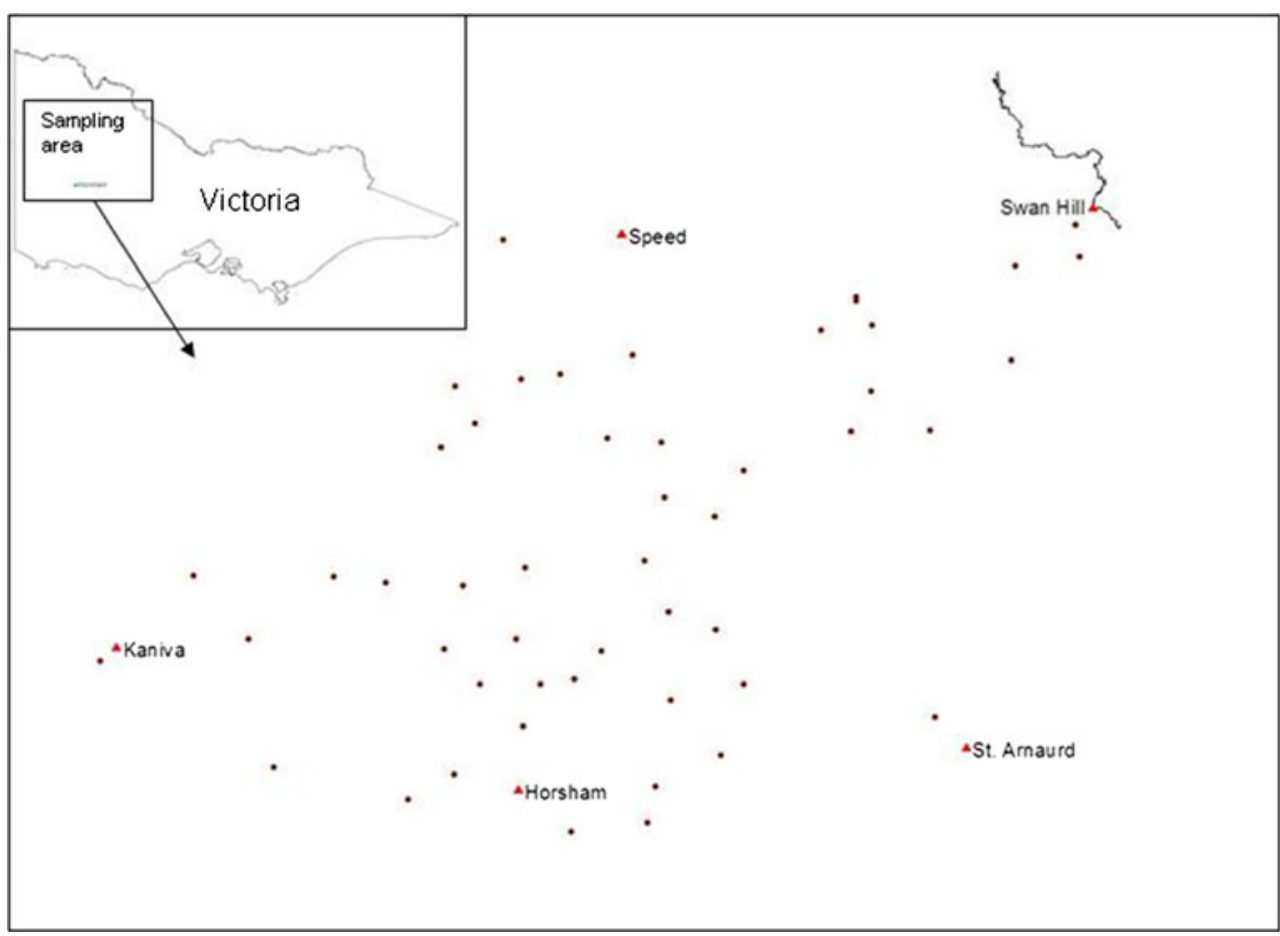




\section{Discussion}

Morrall (1997) reviewed the history of ascochyta blight, anthracnose, and botrytis, three diseases that have affected lentil since its introduction into western Canada 25 years previously. Anthracnose caused by $C$. truncatum sensu lato was reported in Manitoba in 1987 as a new disease. However, despite the severe symptoms, the disease had been dismissed as non-descript dead patches in crops, caused by root rots. Morrall interestingly noted that anthracnose was also not identified during an extensive lentil disease survey in Saskatchewan in 1988, possibly due to widespread drought that year. However, it was identified in 1990 in a small area of Saskatchewan (Morrall and Pedersen 1991) and consequently in 1991 it was found in all major lentil growing areas of Saskatchewan, indicating the disease had been present but undetected for some time (Morrall et al. 1992).

Previous experience in Australia with lupin anthracnose caused by Colletotrichum lupini (Nirenberg et al. 2002) has found the disease to spread rapidly in crop and ornamental lupins under favourable conditions (Sweetingham et al. 1995; Lindbeck et al. 1998). It is thought that C. truncatum sensu lato may have the potential to spread quickly in a similar manner, causing the disease to establish rapidly under favourable conditions in Australia (Ford et al. 2004; Lindbeck and Ford 2005).

From experiences in Canada, lentil anthracnose had most likely been present for some time before being identified (Morrall 1997), highlighting the need for regular, targeted, surveillance surveys in Australia and correct identification of diseased plants. Accurate diagnosis of disease, based on symptoms, is not always possible. Early detection is critical and may prevent a large scale incursion of the disease, increasing the likelihood of eradication. This study demonstrated that high throughput real-time PCR is suitable for routine surveillance surveys of lentil crops for lentil anthracnose. Large numbers of samples were collected, over a large area and could be processed relatively quickly. This method was also shown to be appropriate for use in response to a suspected incursion of lentil anthracnose where rapid and accurate pathogen identification would be required.
Acknowledgments DPI Victoria TopCrop staff for collecting the survey samples and Shane King for mapping the data.

\section{References}

Buchwaldt L, Morrall RAA, Chongo G, Bernier CC (1996) Windborne dispersal of Colletotrichum truncatum and survival in infested lentil debris. Phytopathology 86:1193-1198

Damm U, Woudenberg JHC, Cannon PF, Crous PW (2009) Colletotrichum species with curved conidia from herbaceous hosts. Fungal Divers 39:45-87

Ford R, Banniza S, Photita W, Taylor PWJ (2004) Morphological and molecular discrimination of Colletotrichum truncatum causing anthracnose on lentil in Canada. Australas Plant Pathol 33:559 569

Gossen BD, Anderson KL, Buchwaldt L (2009) Host specificity of Colletotrichum truncatum from lentil. Can J Plant Pathol 31:6573

Latunde-Dada AO, Lucas JA (2007) Localized hemibiotrophy in Colletotrichum: cytological and molecular taxonomic similarities among $C$. destructivum, $C$. linicola and $C$. truncatum. Plant Pathol 56:437-447

Lindbeck K, Ford R (2005) Lentil anthracnose national diagnostic protocol. A technical report prepared for Plant Health Australia. http://www.planthealthaustralia.com.au/pidd-docs/068\%20$\% 20$ Lentil\%20anthracnose\%20DP\%20-\%202005.pdf

Lindbeck KD, Murray GM, Nikandrow A, Priest M, Dominiak BC (1998) Survey for anthracnose caused by Colletotrichum gloeosporioides in crop lupins (Lupinus angustifolius, L. albus) and ornamental lupins (L. polyphyllus) in New South Wales. Australas Plant Pathol 27:259-262

Morrall RAA (1997) Evolution of lentil diseases over 25 years in western Canada. Can J Plant Pathol 19:197-207

Morrall RAA, Pedersen EA (1991) Discovery of lentil anthracnose in Saskatchewan in 1990. Can Plant Dis Surv 71:105-106

Morrall RAA, McCallum BD, Bernier CC (1989) Anthracnose and other diseases of lentil in Manitoba in 1988. Can Plant Dis Surv 69:66

Morrall RAA, Thomson JR, Bond SJ, Downing JL, May-Melin J, Thompson DK (1992) Diseases of lentil in Saskatchewan in 1991. Can Plant Dis Surv 72:80-82

Nirenberg HI, Feiler U, Hagedorn G (2002) Description of Colletotrichum lupini comb. Nov. in modern terms. Mycologia 94:307320

Sweetingham MW, Cowling WA, Buirchell BJ, Brown AGP, Shivas RG (1995) Anthracnose of lupins in Western Australia. Disease notes or new records. Australas Plant Pathol 24:276 